http://dx.doi.org/10.30681/23588403v14i0119

\title{
RESENHA DA OBRA TODOS CONTRA TODOS: O ÓDIO NOSSO DE CADA DIA
}

KARNAL, Leandro. Todos contra todos: o ódio nosso de cada dia. Rio de Janeiro: LeYa, 2017, 144 p.

Mike Ceriani de Oliveira GOMES (IPEMIG) ${ }^{1}$

A obra Todos contra todos: o ódio nosso de cada dia, de autoria do professor e doutor em História Social (USP, 1994) Leandro Karnal (1963), tem por objeto de estudo, assim como sugere o título, as expressões de ódio multiformes no Brasil. O livro conta com análises de expressões de ódio que vão desde as mais explícitas até as que se podem compreender por "mensagem nas entrelinhas", podendo este segundo formato ter representações em ditados populares, letras de canções, usos adverbiais e até mesmo um vocabulário frequentemente empregado no dia a dia, cuja construção histórica vem agregando conotações discriminatórias.

Publicado em 2017, em um cenário de explícita polarização no campo político e de crescentes conflitos ideológicos, o historiador convida seus leitores e leitoras não apenas a se inteirarem de como o ódio passa muitas vezes de forma camuflada pelas pessoas, sem que elas se deem conta, mas também de muitos porquês. Logo em seu prólogo, é apontado pelo autor que, mesmo carecendo de terremotos e tsunamis, "o fundamentalismo religioso, aqui, é mais lembrado pela estética da saia e cabelos compridos que por genocídios" (KARNAL, 2017, p. 7). É preciso salientar que a citação aqui destacada tem um fundamento muito importante para compreender essa e outras obras do autor: Ainda que Leandro Karnal seja abertamente ateu, ele não nega sua grande admiração para as religiões, de forma geral, enquanto objeto de estudo ${ }^{2}$. Além disso, sua colocação sobre o fundamentalismo religioso no Brasil ser "mais lembrado pela estética da saia e cabelos compridos que por genocídios" sintetiza muito bem sua capacidade de observar o mundo de modo a ir além do que é estabelecido pelo senso comum.

\footnotetext{
${ }^{1}$ Especialista em Metodologia de Ensino da Língua Inglesa (2019) pelo Instituto Pedagógico de Minas Gerais IPEMIG; Formação Pedagógica em Letras - Inglês (2019) pela Universidade Norte do Paraná - UNOPAR; MBA em Controladoria e Finanças (2019), Tecnólogo em Gestão de Recursos Humanos (2017) e Bacharel em Administração (2016) pela Faculdade Marechal Rondon - FMR. Professor de Inglês.

${ }^{2}$ Informação disponível em: https://www.youtube.com/watch?v=HS834HHhksM
} 
Em cada capítulo do livro são discorridas as representações do ódio, em vários formatos e contextualizadas em diversos cenários sociais. Passado o prólogo, em que o autor menciona seus principais impulsos até iniciar a escrita e, por fim, a publicação, Karnal convida seus leitores e leitoras a conhecerem sua visão sobre a inércia de brasileiros sobre a violência institucionalizada no país no segundo capítulo, intitulado $O$ paraíso pacifista. Segundo o autor (2017, p. 22), a violência no Brasil é "tolerada, desde que aplicada a grupos sociais específicos". Este ainda complementa que, ao passo que de forma física e brutal vem atingindo a negros, pobres, homossexuais e transexuais, a violência que atinge a grupos de elite é a manchete de jornal. Em sua argumentação, o historiador argumenta que, de Zumbi dos Palmares (1655-1695) até a Ditadura Militar Brasileira (1964-1985) o país não tem passado imune a um filtro histórico que vem negando ou alterando o caráter de representações de violência explícita, bem esclarecendo o título do capítulo.

No terceiro capítulo, Somos todos racistas?, Leandro Karnal traz um pouco de seu pensamento do capítulo anterior, acrescentando o principal desafio que este julga caber às elites: sair da zona de conforto. É apontado então o uso pejorativo do termo "politicamente correto", justificando uma contraposição ao combate às simbologias racistas e homofóbicas presentes até mesmo em marchinhas de Carnaval. O autor também destaca que, ironicamente, o principal público que se vale desse termo é o público menos sujeito à brutalidade da violência racial e homofóbica.

O quarto capítulo, A violência nossa de cada dia, aborda com enfoque as raízes e representações do machismo e da misoginia no Brasil. É claro, segundo o autor, que tal discriminação, mais do que atacar a mulher em si, ataca o feminino. "Gays mais femininos são mais atacados porque no fundo o que se ataca é a mulher, como se a mulher fosse um mal" (KARNAL, 2017, p. 52). Karnal ainda enfatiza que, tanto o machismo quanto a misoginia, tentem a expandir à medida que movimentos em prol do empoderamento feminino vêm trazendo suas pautas a público, e aí se explica também a forte repulsa contra os movimentos feministas. Mediante tal circunstância, as representações de ódio se dão pelo medo, o medo de que toda uma construção patriarcal perca sua abrangência. Como exemplo ao exposto, Karnal (2017, p. 54) relembra um trecho do livro Le Deuxième Sexe ${ }^{3}$, da autora francesa Simone de Beauvoir, levantado como questão no Enem de 2015 em que é levantada clássica afirmação "não se nasce mulher, torna-se mulher", afirmação essa que põe como biológico feminino a elaboração cultural de uma identidade feminina. No evento em questão,

\footnotetext{
${ }^{3}$ O segundo sexo (PT-BR), publicado na França em 1949.
} 
grupos adeptos à zona de conforto da construção patriarcal despertam um alvoroço e atacam não apenas a ideia da autora, mas o exame em si.

No quinto capítulo, Tudo começou em nós mesmos, Karnal explora diversos objetos e representações de ódio através de moldes históricos e religiosos, tão intrínsecos na sociedade que a reação mais comum da sociedade vem a ser o fatalismo. Até suas conclusões, também são apontadas questões relativas ao binarismo nas representações de ódio, muitas vezes carregadas de estereótipos gerados pela ignorância, a exemplo de se tratar por bandidos eleitores e eleitoras de um determinado partido político, bem como os eleitores de um partido conflitante como nazistas. O ódio então impera na autoafirmação de que se um lado está certo, o outro está errado e vice-versa. O historiador vai além e aponta como outro exemplo o fenômeno da demonização a toda pessoa ou ideia adversa de quem usa esse tipo de discurso: um locutor, preso a sua mentalidade de superioridade moral por se colocar como um indivíduo "de deus" ataca seu receptor, classificando-o como um agente "do demônio", pois este não partilha de um determinado ideal. Sua fé e/ou religiosidade vem a ser uma ferramenta de imunidade ao proferir discursos de ódio.

O sexto capítulo, $O$ amor contra o dragão da maldade e da inveja, aborda de modo ainda mais abrangente as representações do ódio a partir da demonização enquanto ferramenta estratégica para justificar diversas atrocidades no mundo. Com isso, é argumentado que, desde que uma atrocidade seja realizada em nome de deus, esta é permitida e "santificada". O autor, por outro lado, não se vale de uma crítica à religiosidade, mas à sua justificativa nas representações de ódio que, por outras vias, não seriam absolvidas.

No sétimo capítulo, A globalização não aumentou o ódio, Karnal afirma e traça exemplos históricos de como a tecnologia foi passiva nas representações de ódio em guerras e no ciclo social. Em um exemplo bem claro, Karnal (2017, p. 93) expõe as sangrentas batalhas napoleônicas (entre o fim do século XVIII e início do século XIX) e a bomba atômica, que em 1945 viria a detonar em Hiroshima: sempre houve raízes de ódio, a única coisa que a tecnologia trouxe é a eficiência de causar mais estragos de modo menos trabalhoso. Vale reforçar que, nesse ponto, o autor não busca isentar genocídios em larga escala, mas dissociar a falsa relação entre intensidade de ódio e poder de extermínio.

O oitavo capítulo, A internet facilita a vida de quem odeia, se trata de uma posição complementar à anterior, trazendo como objeto de análise as representações de ódio propagadas nas redes sociais. Karnal (2017, p. 107-108) argumenta que, cem anos atrás, se fosse racista, precisaria expressar seu ódio em um livro, o que o tomaria meses durante o 
processo de escrita, revisão, editoração e vendas, mas hoje, basta um post em alguma rede social para que possa expressar seu racismo e que este ganhe notoriedade em um curto espaço de tempo. Assim como genocídios em guerras, a tecnologia impulsionou a rede social a expressar com mais eficiência sentimentos e ideias nada autênticos.

No nono capítulo, A violência da política, Leandro Karnal traz mais uma vez as redes sociais como recurso de exteriorização de ódio tendo por alvo agentes políticos. A constatação chave da rede social no processo de demonstrações públicas de desafeto e falta de representatividade para com a classe política é justamente sua capacidade de levar seus sentimentos a público. A corrupção não enfraquece ao passo que cai nas discussões em redes sociais, nem surgiram a partir delas. Karnal (2017, p. 133) fecha o capítulo com suas opiniões a respeito de uma mudança efetiva. Como o autor argumenta, as redes sociais podem até potencializar uma discussão em questões de acesso público e extensão geográfica, mas não pode gerar mudanças que devem ser feitas pela base, mediante uma reestruturação social - o que também não pode ocorrer por redes sociais.

O décimo e último capítulo, Duas soluções: coerção e consenso, o autor realiza um fechamento falando sobre o que entende pela solução natural do problema do ódio. Para Karnal (2017, p. 138), a origem de muitos focos de ódio está justamente na reprodução, enfatizando que para que se quebre essa corrente, o ódio deve deixar de ser ensinado às crianças. A partir daí, o autor cria duas linhas de ação complementares: a coerção, tratando-se da criação de barreiras legais, a fim de que as demonstrações de ódio sejam barradas em qualquer espécie e por qualquer público, independente da natureza e intenção de cada um que o pratica; a segunda ação seria o consenso, e aí entra a necessidade de se conhecer o ódio, suas raízes, seus porquês e, como sugere o nome, mediante o consenso coletivo, minimizar suas representações no meio social.

Há de se reforçar, porém, que o historiador não coloca o ódio como um absoluto mal, ao menos se consideradas as várias possibilidades como ele pode ser tratado. Através de uma ótica diferenciada, Karnal (2017, p. 142) afirma que o ódio, sendo resposta da fraqueza de quem o sente, torna-se automaticamente uma oportunidade pedagógica de autoconhecimento. Saber quem ou o que odeia e o porquê pode ser o mesmo que saber o que no pessoal de cada um deve ser trabalhado para a construção de um ser humano melhor.

Sendo o objeto de estudo, ou seja, o ódio, assunto que pode transcender quaisquer níveis de instrução de participantes que o debatam, passa a ganhar mais relevância na obra enquanto material a ser analisado em aspectos científicos. Vê-se que se trata de uma produção 
elaborada na luz de um forte rigor metodológico, por outro lado, o autor apresenta-a em uma linguagem de fácil compreensão.

\section{REFERÊNCIAS}

KARNAL, Leandro. Todos contra todos: o ódio nosso de cada dia. Rio de Janeiro: LeYa, 2017, 144 p.

SABER FILOSÓFICO. Por que virei ateu? Leandro Karnal. (2019). Disponível em: https://www.youtube.com/watch?v=HS834HHhksM. Acesso em 22 abr. 2020. 